ISSN 0258-7122

Bangladesh J. Agril. Res. 36(2) : 247-253, June 2011

\title{
UPTAKE OF DIFFERENT NUTRIENT ELEMENTS BY LEGUME CROPS IN WHEAT -LEGUME- T. AMAN CROPPING PATTERN
}

\author{
M. J. U. SARKER ${ }^{1}$, M. A. SIDDIKY ${ }^{2}$, M. JAHIRUDDIN ${ }^{3}$ \\ M. H. MIAN ${ }^{4}$ AND M. S. ISLAM ${ }^{5}$
}

\begin{abstract}
A study on nutrient uptake by different legume crops was carried out at two locations-one at Bangladesh Agricultural University farm Mymensingh and another at Regional Agricultural Research Station of Bangladesh Agricultural Research Institute, Jamalpur. The objective was to find out the optimum concentrations of different nutrient elements and its uptake by legume crops in a Wheat-Legume-T. Aman cropping pattern. The uptake of different elements was markedly varied by legume crops at both the locations in two consecutive years of the study. It was also noticed that cowpea removed the highest quantity of nutrient elements from the soils in the treated plots compared to mungbean and blackgram. Besides, stover received the maximum contents of potassium followed by nitrogen, phosphorus, and sulphur which was significantly different over legume seeds.
\end{abstract}

Keywords: Nutrient uptake, legume crops.

\section{Introduction}

The practice of crop rotation with green/brown manure crops and use of farmyard manure is important for sustenance of soil fertility in Bangladesh. The inclusion of leguminous crops into cereal farming system is important for their long-term sustainability, primarily because legumes fix atmospheric nitrogen which would be useful to the following rice crop after incorporation of their residues (Chalk, 1998; Cho et al., 2001). Further, legumes in rotation with crops can also increase organic matter content of soil (Schulz et al., 1999). As viewed by Ladha et al. (1992) and Ladha and Peoples (1995), biologically N- fixing systems offer an economically attractive and ecologically sound means of reducing internal inputs of industrial $\mathrm{N}$ fertilizers, and saving internal resources. Food legumes, such as mungbean, cowpea, and blackgram should receive due attention for evaluating the sources of organic matter, nutrient supply and to produce certain amount of grains in the cropping system.

The magnitude of the residual effect depends on the legume species and the succeeding crop species. In the semi-arid tropics, residual $\mathrm{N}$ contribution by legumes to the succeeding crop has been estimated to be usually equivalent to

${ }^{1}$ Principal Scientific Officer, ${ }^{2}$ Senior Scientific Officer, Soil Science Division, Bangladesh Agricultural Research Institute (BARI), Gazipur, ${ }^{3 \& 4}$ Professor, Bangladesh Agricultural University (BAU), ${ }^{5}$ DG (Former), BARI, Gazipur, Bangladesh. 
30-40 kg N, ha (Rupella and Saxena, 1989: Rego and Burford, 1992). A green manure that decomposes slowly releases little of its $\mathrm{N}$ for the first crop and will have a large effect on the second crop (Bouldin, 1988). According to Mohanty et al. (1998), green manuring encourages the recovery of fertilizer $\mathrm{N}$. The use of green manure to rice has been reported to increase the yield of subsequent wheat crop due to residual effect (Yadav et al., 2000). Residual benefit of legume incorporation is commonly assessed mainly in terms of increased grain and dry matter yields.

In tropical areas like Bangladesh, blackgram, mungbean, and cowpea, which mature in 60-70 days, can easily be grown as a short duration summer pulse crop between wheat and rice. Wheat-Fallow-T. Aman rice is a dominant cropping pattern in Bangladesh. The inclusion of food legumes in the fallow period will supply biomass to soil that would improve soil health by adding nitrogen and organic matter to the soil. Hence, the present study was undertaken to determine the benefits of growing food legumes (blackgram, cowpea, and mungbean) in the rice-wheat cropping system by assessing nutrient uptake by the legume components.

\section{Materials and Method}

A field study was conducted to assess and estimate the nutrient uptake by legume crops at Bangladesh Agricultural University farm, Mymensingh and Regional Agricultural Research Station, Jamalpur for two consecutive years. Both the experimental fields belong to agroecological zone of old Brahmaputra Floodplain (AEZ-9) soils. The initial soils of the experimental sites $(0-15 \mathrm{~cm})$ were analyzed for physical and chemical properties before setting up the field experiments. The physico-chemical properties are shown in (Table 1). Both soils were silt loam in texture having near neutral soil $\mathrm{pH}$ with low to moderate soil fertility. Three legume crops, such as blackgram, cowpea and mungbean were used in the study as test crops, the varieties of the pulses were as BARI Mash-I (Blackgram), BARI Fallon-1 (Cowpea), and BARI Mung-2 (Mungbean). The legume seeds were sown in the last week of March during Kharif-I season in each year. The individual plot size $(5 \mathrm{~m} \times 3 \mathrm{~m})$ was adjusted in meeting the objectives of the study. The seeds were coated with Bradyrhizobium inoculants. The legume crops were fertilized with P, K, and S @ 20-30-15 kg/ha during final land preparation. The cereal crop wheat before legume received $\mathrm{N}_{118} \mathrm{P}_{52} \mathrm{~K}_{95} \mathrm{~S}_{32} \mathrm{~kg} / \mathrm{ha}$ fertilizers at BAU farm and $\mathrm{N}_{108} \mathrm{P}_{49} \mathrm{~K}_{84} \mathrm{~S}_{29} \mathrm{~kg} / \mathrm{ha}$ at RARS farm, Jamalpur. The post legume rice crop was fertilized with $\mathrm{N}_{90} \mathrm{P}_{22} \mathrm{~K}_{65} \mathrm{~S}_{40} \mathrm{~kg} / \mathrm{ha}$ at BAU farm and $\mathrm{N}_{80} \mathrm{P}_{20} \mathrm{~K}_{55}$ $\mathrm{S}_{40} \mathrm{~kg} / \mathrm{ha}$, at RARS farm, Jamalpur. The necessary intercultural operations were performed in time as needed by the crops. After two to three pickings of the matured pods, the legume plants were chopped and incorporated in-situ one week before transplanting T. Aman rice in both the locations. The plant parts (Seeds and Stover samples) were collected from each plot and analyzed for nutrient elements chemically following standard methods. 
Table 1. Physico-chemical properties of the initial soils of the experimental fields.

\begin{tabular}{|c|c|c|c|c|c|c|c|c|c|c|c|c|c|c|}
\hline \multirow{2}{*}{ Location } & \multirow{2}{*}{$\begin{array}{c}\text { Textural } \\
\text { class }\end{array}$} & \multirow{2}{*}{$\mathrm{pH}$} & \multirow{2}{*}{$\begin{array}{c}\mathrm{OM} \\
\%\end{array}$} & $\mathrm{Ca}$ & $\mathrm{Mg}$ & K & \multirow{2}{*}{$\begin{array}{l}\text { Total } \\
\text { N\% }\end{array}$} & $\mathrm{P}$ & $S$ & B & $\mathrm{Cu}$ & $\mathrm{Fe}$ & $\mathrm{Mn}$ & $\mathrm{Zn}$ \\
\hline & & & & & $q / 10$ & & & \multicolumn{7}{|c|}{$\mu \mathrm{g} / \mathrm{g}$} \\
\hline $\begin{array}{l}\text { BAU farm, } \\
\text { Mymensingh }\end{array}$ & $\begin{array}{l}\text { Silty } \\
\text { loam }\end{array}$ & 6.9 & 1.76 & 4.8 & 1.8 & 0.03 & 0.095 & 2.2 & 4.7 & 0.47 & 2.0 & 22 & 6 & 1.9 \\
\hline $\begin{array}{l}\text { RARS farm, } \\
\text { Jamalpur }\end{array}$ & $\begin{array}{l}\text { Silty } \\
\text { loam }\end{array}$ & 6.8 & 1.93 & 3.5 & 1.6 & 0.08 & 0.117 & 4.2 & 13.5 & 0.32 & 2.6 & 50 & 16 & 1.6 \\
\hline Critical level & & - & - & 2.0 & 0 & 02 & - & 14 & 14 & 02 & 1.0 & 10 & 5.0 & 2.0 \\
\hline
\end{tabular}

\section{Results and Discussion}

Nitrogen uptake

At BAU farm, the average $\mathrm{N}$ uptake by blackgram seed was $12.72 \mathrm{~kg} / \mathrm{ha}$ in 2000 and that in 2001 was $14.09 \mathrm{~kg} / \mathrm{ha}$ (Table 2). Nitrogen uptake by blackgram stover was 26.95 and $25.38 \mathrm{~kg} / \mathrm{ha}$ for the years 2000 and 2001, respectively. In case of cowpea, the seed $\mathrm{N}$ uptake were $26.51 \& 26.32 \mathrm{~kg} / \mathrm{ha}$ and the stover $\mathrm{N}$ uptake were 31.67 and $30.78 \mathrm{~kg} / \mathrm{ha}$ in 2000 and 2001, respectively. The seed $\mathrm{N}$ uptake by mungbean was found to be $18.70 \& 20.44 \mathrm{~kg} / \mathrm{ha}$ and the stover $\mathrm{N}$ uptake was $29.73 \& 29.00 \mathrm{~kg} / \mathrm{ha}$ in the respective two years.

Table 2. Nitrogen uptake by different food legumes at BAU farm.

\begin{tabular}{l|c|c|c|c}
\hline \multirow{2}{*}{ Legume } & \multicolumn{4}{c}{ N uptake $(\mathrm{kg} / \mathrm{ha})$} \\
\cline { 2 - 5 } & \multicolumn{2}{|c}{2000} & \multicolumn{2}{c}{2001} \\
\cline { 2 - 5 } & Seed & Stover & Seed & Stover \\
\hline Blackgram & $12.72 \pm 0.72$ & $26.95 \pm 1.67$ & $14.09 \pm 0.63$ & $25.38 \pm 1.32$ \\
Cowpea & $26.51 \pm 0.71$ & $31.67 \pm 1.81$ & $26.32 \pm 0.86$ & $30.78 \pm 138$ \\
Mungbean & $18.70 \pm 0.66$ & $29.73 \pm 1.62$ & $20.44 \pm 0.95$ & $29.00 \pm 1.23$ \\
\hline
\end{tabular}

Results are the means \pm SD of 15 observations.

At RARS Jamalpur, the mean $\mathrm{N}$ uptake by blackgram seed was 14.98 \& $14.81 \mathrm{~kg} / \mathrm{ha}$ and by stover $26.91 \& 26.86 \mathrm{~kg} / \mathrm{ha}$ in 2000 and 2001 , respectively (Table 3). In cowpea, the seed $\mathrm{N}$ uptake was $26.96 \& 27.71 \mathrm{~kg} / \mathrm{ha}$, and the stover $\mathrm{N}$ uptake was $33.18 \& 32.65 \mathrm{~kg} / \mathrm{ha}$ in the consecutive two years. The average $\mathrm{N}$ uptake by mungbean seed was $21.34 \& 22.12 \mathrm{~kg} / \mathrm{ha}$ in the respective two years and the corresponding stover $\mathrm{N}$ was $30.22 \& 30.08 \mathrm{~kg} / \mathrm{ha}$. The grain yields of blackgram, cowpea, and mungbean were $518,825 \& 612 \mathrm{~kg} / \mathrm{ha}$, respectively, at BAU and 648, 840 and $705 \mathrm{~kg} / \mathrm{ha}$, respectively, at RARS Jamalpur in the year 2000. In 2001 the yields were 559, 814, and $664 \mathrm{~kg} / \mathrm{ha}$, respectively, at BAU and 643, 868, and $734 \mathrm{~kg} / \mathrm{ha}$, respectively, at RARS Jamalpur. Likewise the stover yields of blackgram, cowpea, and mungbean were 2178,2317 , and $2223 \mathrm{~kg} / \mathrm{ha}$, 
respectively, at BAU and 2158, 2363, and $2227 \mathrm{~kg} / \mathrm{ha}$, respectively, at RARS Jamalpur in the year 2000. In 2001, the yields were 2152, 2323, and $2215 \mathrm{~kg} / \mathrm{ha}$, respectively, at BAU and 2185, 2343, and $2219 \mathrm{~kg} / \mathrm{ha}$, respectively, at RARS Jamalpur.

Table 3. Nitrogen uptake by different food legumes at RARS Jamalpur farm.

\begin{tabular}{l|c|c|c|c}
\hline \multirow{2}{*}{ Legume } & \multicolumn{4}{|c}{ N uptake $(\mathrm{kg} / \mathrm{ha})$} \\
\cline { 2 - 5 } & \multicolumn{2}{|c}{2000} & \multicolumn{2}{c}{2001} \\
\cline { 2 - 5 } & Seed & Stover & Seed & Stover \\
\hline Blackgram & $14.98 \pm 0.58$ & $26.91 \pm 1.32$ & $14.81 \pm 0.57$ & $26.86 \pm 1.04$ \\
Cowpea & $26.96 \pm 0.73$ & $33.18+1.70$ & $27.71 \pm 0.61$ & $32.65 \pm 1.53$ \\
Mungbean & $21.34 \pm 0.68$ & $30.22 \pm 1.38$ & $22.12 \pm 0.94$ & $30.08 \pm 1.85$ \\
\hline
\end{tabular}

Results are the means \pm SD of 15 observations.

\section{Phosphorus uptake}

At BAU farm, the mean P uptake by blackgram seed in the two years was 1.41 and $1.54 \mathrm{~kg} / \mathrm{ha}$ and that by stover was 3.30 and $3.19 \mathrm{~kg} / \mathrm{ha}$, respectively (Table 4). The $P$ uptake by cowpea seed was $3.72 \mathrm{~kg} / \mathrm{ha}$ in 2000 and $3.77 \mathrm{~kg} / \mathrm{ha}$ in 2001 , and the respective stover $P$ uptake were 5.33 and $5.29 \mathrm{~kg} / \mathrm{ha}$. For mungbean, the seed P uptake were found as 1.96 and $2.12 \mathrm{~kg} / \mathrm{ha}$ and the stover P uptake were 3.83 and $3.77 \mathrm{~kg} / \mathrm{ha}$, respectively.

Table 4. Phosphorus uptake by different food legumes at BAU farm.

\begin{tabular}{l|c|c|c|c}
\hline \multirow{2}{*}{ Legume } & \multicolumn{4}{c}{ P uptake $(\mathrm{kg} / \mathrm{ha})$} \\
\cline { 2 - 5 } & \multicolumn{2}{|c}{2000} & \multicolumn{2}{c}{2001} \\
\cline { 2 - 5 } & Seed & Stover & Seed & Stover \\
\hline Blackgram & $1.41 \pm 0.12$ & $3.30 \pm 0.18$ & $1.54+0.15$ & $3.19 \pm 0.16$ \\
Cowpea & $3.72 \pm 0.20$ & $5.33 \pm 0.13$ & $3.77 \pm 0.27$ & $5.29 \pm 0.19$ \\
Mungbean & $1.96 \pm 0.07$ & $3.83 \pm 0.28$ & $2.12 \pm 0.11$ & $3.77 \pm 0.23$ \\
\hline
\end{tabular}

Results are the means \pm SD of 15 observations.

At RARS Jamalpur, the mean P uptake of 1.66 and $1.57 \mathrm{~kg} /$ ha by seed and 3.11 and $108 \mathrm{~kg} / \mathrm{ha}$ by stover were obtained with blackgram in 2000 and 2001, respectively (Table 5). The $\mathrm{P}$ uptake by cowpea seed was 3.89 and $3.91 \mathrm{~kg} / \mathrm{ha}$, and by stover was $5.40 \& 5.28 \mathrm{~kg} / \mathrm{ha}$ during the two years, respectively. In mungbean, the $\mathrm{P}$ uptake was $2.07 \& 2.04 \mathrm{~kg} / \mathrm{ha}$ for seed and 3.98 and $3.95 \mathrm{~kg} / \mathrm{ha}$ for stover in the respective two years. 
Table 5. Phosphorus uptake by different food legumes at RARS Jamalpur farm.

\begin{tabular}{l|c|c|c|c}
\hline \multirow{2}{*}{ Legume } & \multicolumn{4}{|c}{ P uptake $(\mathrm{kg} / \mathrm{ha})$} \\
\cline { 2 - 5 } & \multicolumn{2}{|c}{2000} & \multicolumn{2}{c}{2001} \\
\cline { 2 - 5 } & Seed & Stover & Seed & Stover \\
\hline Blackgram & $1.66 \pm 0.19$ & $3.11 \pm 0.16$ & $1.57 \pm 0.19$ & $3.08 \pm 0.14$ \\
Cowpea & $3.89 \pm 0.21$ & $5.40 \pm 0.21$ & $3.91 \pm 0.13$ & $5.28 \pm 0.25$ \\
Mungbean & $2.07 \pm 0.11$ & $3.98 \pm 0.21$ & $2.04 \pm 0.13$ & $3.95 \pm 0.23$ \\
\hline
\end{tabular}

Results are the means \pm SD of 15 observations.

\section{Potassium uptake}

The K uptake by blackgram seeds were found to be 6.85 and $7.49 \mathrm{~kg} / \mathrm{ha}$ and by stovers were 33.54 and $32.54 \mathrm{~kg} / \mathrm{ha}$ as recorded at BAU farm in 2000 and 2001, respectively (Table 6). This element uptaken by cowpea was 12.40 and 59.88 $\mathrm{kg} / \mathrm{ha}$ in 2000 and 12.47, and $59.60 \mathrm{~kg} / \mathrm{ha}$ in 2001 for seed and stover, respectively. In mungbean, the seed $\mathrm{K}$ uptake was recorded as 8.38 and 9.25 $\mathrm{kg} / \mathrm{ha}$, and the stover K uptake was 35.59 and $35.19 \mathrm{~kg} / \mathrm{ha}$ in the two years, respectively.

Table 6. Potassium uptake by different food legumes at BAU farm.

\begin{tabular}{l|c|c|c|c}
\hline \multirow{2}{*}{ Legume } & \multicolumn{4}{c}{ K uptake $(\mathrm{kg} / \mathrm{ha})$} \\
\cline { 2 - 5 } & \multicolumn{2}{c}{2000} & Seed & Stover \\
\cline { 2 - 5 } & Seed & Stover & $7.49 \pm 0.33$ & $32.54 \pm 1.72$ \\
Blackgram & $6.85 \pm 0.38$ & $33.54 \pm 1.93$ & $12.47 \pm 0.48$ & $59.60 \pm 2.76$ \\
Cowpea & $12.40 \pm 0.42$ & $59.88 \pm 2.49$ & $9.25 \pm 0.43$ & $35.19 \pm 1.58$ \\
Mungbean & $8.38 \pm 0.35$ & $35.59 \pm 2.02$ & 9.01 \\
\hline
\end{tabular}

Results are the means \pm SD of 15 observations.

At RARS Jamalpur in blackgram, the mean K uptake of 8.56 and $8.41 \mathrm{~kg} / \mathrm{ha}$ by seed and 32.56 and $33.06 \mathrm{~kg} / \mathrm{ha}$ by stover were observed in 2000 and 2001 , respectively (Table 7). The $\mathrm{K}$ uptake by cowpea seed was $12.38 \& 12.61 \mathrm{~kg} / \mathrm{ha}$ and by its stover $61.04 \& 60.66 \mathrm{~kg} / \mathrm{ha}$ in the consecutive two years. The $\mathrm{K}$ uptake of 9.51 and $9.64 \mathrm{~kg} / \mathrm{ha}$ by seed and $35.46 \& 35.37 \mathrm{~kg} / \mathrm{ha}$ by stover were obtained with mungbean during 2000 and 2001, respectively.

Table 7. Potassium uptake by different food legumes at RARS Jamalpur farm.

\begin{tabular}{l|c|c|c|c}
\hline \multirow{2}{*}{ Legume } & \multicolumn{4}{|c}{ K uptake $(\mathrm{kg} / \mathrm{ha})$} \\
\cline { 2 - 5 } & \multicolumn{2}{|c}{2000} & \multicolumn{2}{c}{2001} \\
\cline { 2 - 5 } & Seed & Stover & Seed & Stover \\
\hline Blackgram & $8.56 \pm 0.35$ & $32.56 \pm 2.05$ & $8.41 \pm 0.36$ & $33.06 \pm 1.76$ \\
Cowpea & $12.38 \pm 0.42$ & $61.04 \pm 2.35$ & $12.61 \pm 0.31$ & $60.66 \pm 2.74$ \\
Mungbean & $9.51 \pm 0.31$ & $35.46 \pm 1.77$ & $9.64 \pm 0.68$ & $35.37 \pm 1.96$ \\
\hline
\end{tabular}

Rsults are the means \pm SD of 15 observations. 


\section{Sulphur uptake}

At BAU farm, in blackgram the seed S uptake was $1.10 \mathrm{~kg} / \mathrm{ha}$ for both the years, the stover S uptake being 2.52 and $2.45 \mathrm{~kg} / \mathrm{ha}$ in 2000 and 2001, respectively (Table 8 ). The $\mathrm{S}$ uptake by cowpea seed in both the years was $1.72 \mathrm{~kg} / \mathrm{ha}$, and by stover were $2.93 \& 2.91 \mathrm{~kg} / \mathrm{ha}$ in the two years, respectively. The mungbean seed removed S@1.23 and $1.34 \mathrm{~kg} / \mathrm{ha}$, and stover $2.72 \& 2.69 \mathrm{~kg} / \mathrm{ha}$ in the consecutive two years.

Table 8. Sulphur uptake by different food legumes at BAU farm.

\begin{tabular}{l|c|c|c|c}
\hline \multirow{2}{*}{ Legume } & \multicolumn{4}{|c}{ S uptake (kg/ha) } \\
\cline { 2 - 5 } & \multicolumn{2}{|c}{2000} & \multicolumn{2}{c}{2001} \\
\cline { 2 - 5 } & Seed & Stover & Seed & Stover \\
\hline Blackgram & $1.10 \pm 0.08$ & $2.52 \pm 0.15$ & $1.10 \pm 0.08$ & $2.45 \pm 0.14$ \\
Cowpea & $1.72 \pm 0.12$ & $2.93 \pm 0.11$ & $1.72 \pm 0.12$ & $2.91 \pm 0.14$ \\
Mungbean & $1.23 \pm 0.06$ & $2.72+0.18$ & $1.34 \pm 0.11$ & $2.69 \pm 0.19$ \\
\hline
\end{tabular}

Results are the means \pm SD of 15 observations.

The mean $\mathrm{S}$ uptake by blackgram seed at RARS Jamalpur was $1.29 \& 1.20$ $\mathrm{kg} / \mathrm{ha}$ and $2.46 \& 2.50 \mathrm{~kg} / \mathrm{ha}$ by stover in two years, respectively (Table 9). The $\mathrm{S}$ uptake by cowpea seed was $1.71 \& 1.75 \mathrm{~kg} / \mathrm{ha}$ and by stover 2.96 to $2.97 \mathrm{~kg} / \mathrm{ha}$ in the respective two years. In mungbean, the average $\mathrm{S}$ uptake was $1.38 \mathrm{~kg} / \mathrm{ha}$ by seed in both years and $2.76 \& 2.74 \mathrm{~kg} / \mathrm{ha}$ by stover during 2000 and 2001 , respectively.

Table 9. Sulphur uptake by different food legumes at RARS Jamalpur farm.

\begin{tabular}{l|c|c|c|c}
\hline \multirow{2}{*}{ Legume } & \multicolumn{4}{|c}{ S uptake $(\mathrm{kg} / \mathrm{ha})$} \\
\cline { 2 - 5 } & \multicolumn{2}{|c}{2000} & \multicolumn{2}{c}{2001} \\
\cline { 2 - 5 } & Seed & Stover & Seed & Stover \\
\hline Blackgram & $1.29 \pm 0.09$ & $2.46 \pm 0.13$ & $1.20 \pm 0.07$ & $2.50 \pm 0.16$ \\
Cowpea & $1.71+0.10$ & $2.96 \pm 0.17$ & $1.75+0.08$ & $2.97 \pm 0.16$ \\
Mungbean & $1.38 \pm 0.08$ & $2.76 \pm 0.15$ & $1.38 \pm 0.09$ & $2.74 \pm 0.20$ \\
\hline
\end{tabular}

Results are the means + SD of 15 observations.

\section{Conclusion}

From the studies, it may be conducted that the highest nutrient uptake was achieved by cowpea, which was followed by mungbean and blackgram. The three legume crops in the pattern received similar type of fertilizer inputs but their nutrient use efficiency and total biomass production varied. It may be noted here that cowpea would be the best legume crop in respect of pulse yield and 
biomass incorporation to improve soil health and sustainable yield of the cropping pattern due to its high nutrient uptake. However, the decomposition rate of cowpea should be looked at before so that the recommendation be most beneficial.

\section{References}

Bouldin, D.R. 1988. Effect of green manure on soil organic matter content and nitrogen availability. Proceedings of a symposium on "Sustainable Agriculture, Green Manure Crops in Rice Farming”. IRRI pp. 151-163.

Chalk, P.M. 1998. Dynamics of biologically fixed N in legume-cereal rotations: A review. Aust. J. Agric. Res. 49: 303-316.

Cho. Y.S., Z.R. Choc. and S.E. Ockerby. 2001. Managing tillage, sowing rate and nitrogen top-dressing level to sustain rice yield in a low-input, direct-sown, ricevetch cropping system. Aust. J. Expt. Agric. 41: 61-69.

Ladha, J. K., T. George and B. B. Bohlol. 1992. Biological nitrogen fixation for sustainable agriculture. Dordrecht, Netherlands: Kiuwer Aca. Pub. p. 209.

Ladha, J. K. and M. B. Peoples. 1995. Management of biological nitrogen fixation for the development of more productive and sustainable agricultural systems. Dordrecht. Netherlands: Kiuwer Aca. Pub. p. 287.

Mohanty, S. K., M.M. Panda, A.R. Mosier, P. Mohapatra and M. D. Reddy. 1998. $15^{\mathrm{N}}$ balance in rice -green gram-rice cropping system. J. Indian Soc. Soil Sci. 46: 232238.

Rego, T.G. and J.R. Burford. 1992. Sustaining crop productivity on rainfed vertisols through grain legumes. Agronomy Abstracts. Annual meeting, Madison, USA. American Society of Agronomy.

Rijpma, J. and M. Jahiruddin. 2004. National Strategy and Plan for Use of Soil Nutrient Balance in Bangladesh. A Consultancy Report. SFFP, Khamarbari, Dhaka.

Rupella, P. and M.C. Saxena. 1989. Nodulation and nitrogen fixation in chickpea. In Chickpea, Saxena, M.C. and K.B. Eds., Walingford, Oxon, UK; CAB, International. pp. 191-206.

Schulz, S., J.D.H. Keatinge and G.J. Wells. 1999. Productivity and residual effects of legumes in rice based cropping systems in a warm temperature environment. I Legume biomass production and N fixation. Field Crops Res. 61: 23-35.

Yadav, R. L., B. S. Dwivedi and P.S. Pandey. 2000. Rice-wheat cropping system: assessment of sustainability under green manuring and chemical fertilizer inputs. Field Crops Res. 65: 15-30. 